\title{
Working from Home (WFH), the \\ New Reality: A Human Science Perspective during the COVID-19 Pandemic
}

\author{
Shanta Balgobind Singh \\ ORCID iD: https://orcid.org/0000-0001-9469-6552
}

\section{Gerelene Jagganath \\ ORCID iD: http://orcid.org/0000-0002-1051-8968}

\begin{abstract}
Given the global pandemic of COVID-19, the invisible Corona virus, which has brought the entire world into lockdown, and academic institutions into virtual closure and uncertainty, the integrity of the University of KwaZuluNatal (UKZN), has to be maintained within the scenario that is playing out. In the wake of the emergence of new modes of digital communication, higher education has entered a time to undertake robust transformation that has to create new possibilities for collaborative, engaging scholarship and teaching with a goal to advance the vision of the academic institution as an excellent institution in the 21 st century. This would entail combining traditional teaching and research with new forms of digital scholarship intended to involve a wider audience. In this research, online emails were sent to colleagues within the discipline of Criminology and Forensic Studies, School of Applied Human Sciences. This was intended to ascertain staff experiences in trying to disseminate the modules they taught via the online systems available at UKZN during the shutdown period. The study reveals that in leading colleagues towards an achievable goal requires not only orientation and motivation but it is equally imperative to empower people to effectively implement strategies to achieve the shared goals. This requires operative management practices to create an enabling environment to take the disciplines to the next level in shaping the future and changing needs of higher education.
\end{abstract}


Keywords: Higher Education, Online, Covid-19, Digital Communication, Criminology

\section{Introduction}

As the world responds to the Coronavirus (COVID-19) outbreak, higher education institutions have closed campuses. The call for 'social distancing' in the wake of this disease has seen schools and universities around the world suddenly attempting to turn their physical classrooms into virtual ones. In the wake of the emergence of new modes of digital communication, higher education has entered a time of intense transformation that opens new possibilities for more concerted, self-motivated, and engaging scholarship even as it perturbs well-established arrangements and academic practices. From a pedagogic perspective, it has left lecturers urgently trying to reformat their courses while trying not to overly disadvantage large numbers of their students. As a means of supporting those attempting to do their best under demanding circumstances, the University of Kwa Zulu Natal (UKZN) has offered many online platforms for staff to continue working from home (WFH). Although many institutions of higher education started shifting to teaching and learning via virtual platforms, this has suddenly put a strain on educational technology. For those who have been doing online learning or distance education for a while the virtual platforms may have been embraced with encouragement. Nevertheless, those who have not used online teaching and learning as a means of pedagogical dissemination, this mechanism has posed many challenges and the interrelated uncertainty under these circumstances can be disconcerting. This research investigates lecturers (both permanent and fixed term contract) responses to online teaching in the Criminology and Forensic Studies Discipline (CFSD) within the School of Applied Human Sciences (SAHS).

\section{Transitioning from Face-to-face to Online Teaching - International and National views}

Internationally online higher education has grown dramatically over the past two decades, and most higher education institutions believe that this method of instruction will be critical for the future of higher education (Allen \& 
Seaman 2014). In 2014, the National Centre for Education Statistics indicated that over $25 \%$ of the student population at institutions of higher education were taking at least one online course per year. Higher education has offered distance instruction as an option for decades. In addition, financial issues facing many higher education institutions and students' demands shift the focus of these institutions more toward using online education (Limperos et al. 2015).

Literature indicated that educators and learners technical skills related to use of computers and the internet (Peng et al. 2006), their perceptions and attitudes toward the internet (Tsai \& Lin 2004), their cultural and nonEnglish backgrounds (Luyt 2013), and their time management skills (Hill 2002; Roper 2007) are considered important for shaping educators and learners' readiness to participate in online courses. Online teaching poses a challenge to effectively transfer what is taught in the face-to-face classroom to online. Anderson et al. (2011:4) stated that they saw one of the main challenges as the 'disconnect between the way teachers were taught to teach' and how the course content must be delivered in an effective online classroom. This disconnect, while not new, does present a problem as many of the teacher education programs may not have yet caught up to the evolving online teaching environments. Another challenge outlined by Anderson et al. (2011) is the almost non-existence of institutional expectations for their online courses. These include expectations of teachers, students, courses, and staff. Without clear guidelines and expectations for faculty members to follow, there is no way to assess the effectiveness of these online courses. Further Anderson et al. (2011) explained that the feedback they received from students seldom helped them in adjusting their teaching as they would in a face-to-face class.

In the United States of America, the pandemic of COVID-19 has reached all states and many universities have shifted to a forced kind of distance education-to keep teaching while everyone stays at least six feet apart to avoid spreading the virus. Consequently, many lecturers, both at institutions of higher education and at community and governmental organizations, are being called on to adapt their courses to the online environment. Many lecturers/instructors are asked to do this without sufficient training and to effectively translate learning opportunities. Multimedia used in the wrong way can be a detriment to the learning process (Social Science Space 2020). Some lecturers do not have sufficient training to be able to effectively move 
courses to an online format. Nothing is more disconcerting to online students than the missing-in-action lecturer. In online learning, presence is established differently than in a face-to-face classroom. The Community of Inquiry Model, developed in 1999 by Garrison and Anderson and further developed since then (Garrison 2017), describes three kinds of presence: teaching, cognitive, and social. Finding a way to establish and maintain presence is essential, particularly in the current situation where students are accustomed to seeing the instructor and being able to ask questions in class or meet privately. Social presence is significant when students are worried about a global crisis, and in a teaching-and-learning context, social presence and community building can diffuse tension and increase student motivation.

As of 26 March 2020, when the commencement of the lockdown in South Africa was implemented due to the COVID-19, students were out of school and higher education intuitions around the country were closed in order try to contain the spread of the coronavirus. South Africa has 26 universities, 50 technical and vocational education training (TVET) colleges, as well as private higher education institutions, with more than two million students (Khan 2020:1)). This has impacted on university leaders stepping up to jointly create resources online, share best practices, rapidly attempting to train staff in a mode of remote teaching they may never have done, and adapt to a constantly changing environment. Promoting digital fluencies that will enable both students and educators to succeed in an information rich networked world requires human recourse and financial investments. In higher education globally, the impetus has been to ensure that students complete their semester uninterrupted. Multiple online teaching guides, resources, webinars and videos are being prepared in rapid fire to this end to support academics as they upskill to migrate to remote teaching platforms or go fully online. Prolific online resources have mushroomed and the internet and social media are brimming and bursting with new tools, tips and tricks and techniques for the new (quick) fix: toe-the-line by going online (BehariLeak \& Ganas: 2020). So too has the University of KwaZulu-Natal.

\section{What is Online/ Virtual Teaching?}

An early definition of virtual classrooms (sometimes referred to as virtual learning environments [VLEs]) comes from Britain and Liber (1999: 3), who described VLEs as 'learning management software systems that synthesize 
the functionality of computer-mediated communications software and online methods of delivering course materials'. Virtual classrooms usually feature noticeboards for announcements, course outlines, in-system e-mail service, conferencing tools, class lists or student homepages, assignments, assessments, multimedia resources, file upload areas, a calendar, and a navigable boundary (Britain \& Liber 1999; Vai \& Sosulski 2016). Virtual identities generally defined as imaginary people that users create to serve as replacements in an online world (Avgerinou \& Andersson 2007), are widely used online, and students who are steeped in online culture can learn how to navigate the web using a variety of pseudonyms, writing styles, and personality characteristics.

According to Wallace (2009) the asynchronous nature of virtual classrooms is one of their biggest selling points; advanced communications technology (including mobile devices, many of which support online learning platforms) allow for individualized, student centred instruction that can happen on an 'any time, any place' basis. Many virtual classrooms also take advantage of Web 2.0 (defined as highly interactive and collaborative) technologies, such as blogs, learner-generated content, wikis, podcasts, social networking, Skype, Second Life, Zoom and Moodle. The components that make up virtual classrooms have improved considerably in the past decade due to the widespread availability of high-speed internet access and support for video and audio interactivity (Wallace 2009). Much like in brick-and- mortar classrooms, teachers in virtual settings must wear many hats. Their responsibilities involve facilitating asynchronous and synchronous instructtion, leading discussions, assessing student performance, communicating with students via e-mail or phone, and, in some instances, conducting regular tutoring sessions via synchronous media (Vai \& Sosulski 2016). The table below differentiates between different types of programmes in digital learning.

\section{Table 1: Definitions for the Different Technology-Based Education}

\begin{tabular}{|l|l|}
\hline $\begin{array}{l}\text { Blended } \\
\text { learning }\end{array}$ & $\begin{array}{l}\text { Blended learning offers a combination of online and } \\
\text { classroom education, where there is an element of } \\
\text { student control concerning pacing, location, and time in } \\
\text { the online portion. The educator of record is located in a } \\
\text { building, and students spend a significant portion of the } \\
\text { course interacting face-to-face with that educator. } \\
\text { Blended learning is often used interchangeably with }\end{array}$ \\
\hline
\end{tabular}




\begin{tabular}{|c|c|}
\hline & $\begin{array}{l}\text { hybrid learning, but online learning can also be thought } \\
\text { of as a continuum, with students spending more time in a } \\
\text { class when engaged in blended learning, and less time } \\
\text { when engaged in hybrid learning. }\end{array}$ \\
\hline $\begin{array}{l}\text { Digital/online } \\
\text { learning }\end{array}$ & $\begin{array}{l}\text { Digital (or online) learning is an umbrella term that } \\
\text { refers to any instructional practice that uses digital } \\
\text { technology to connect educators and students. Digital } \\
\text { learning 'encompasses a wide range of digital tools and } \\
\text { practices, including instructional content, interactions, } \\
\text { data and assessment systems, learning platforms, online } \\
\text { courses, adaptive software, personal learning enabling } \\
\text { technologies, and student data management systems'. }\end{array}$ \\
\hline $\begin{array}{l}\text { Synchronous } \\
\text { versus } \\
\text { asynchronous } \\
\text { learning }\end{array}$ & $\begin{array}{l}\text { Synchronous learning refers to instruction or activities } \\
\text { that require the instruction and multiple students to be } \\
\text { present in a virtual classroom at the same time. These } \\
\text { 'live virtual sessions' often make use of video, audio and } \\
\text { text communication in an attempt to replicate a brick- } \\
\text { and-mortar class experience. Asynchronous learning, } \\
\text { meanwhile, refers to interactions between users-both } \\
\text { instructors and students-that take place at disparate } \\
\text { times. Discussion boards and wikis are examples of } \\
\text { online tools that make use of asynchronous learning. }\end{array}$ \\
\hline Hybrid course & $\begin{array}{l}\text { While students may still experience face-to-face } \\
\text { interactions with educators and peers in hybrid courses, } \\
\text { the majority of instruction and interaction happens } \\
\text { online, often asynchronously. The online instructor } \\
\text { remains the educator of record, but the students may also } \\
\text { spend face-to-face time with other educators. }\end{array}$ \\
\hline Online course & $\begin{array}{l}\text { An online course takes place primarily over the Internet, } \\
\text { with both educators and students accessing the course } \\
\text { via an online delivery system such as a Learning } \\
\text { Management System (LMS). While students may access } \\
\text { the course either in or out of buildings, there is usually } \\
\text { geographical distance between the educator and the } \\
\text { students. }\end{array}$ \\
\hline
\end{tabular}




\begin{tabular}{|c|c|}
\hline $\begin{array}{l}\text { Virtual/cyber } \\
\text { institutions }\end{array}$ & $\begin{array}{l}\text { Virtual (or cyber) institutions are full-time online } \\
\text { courses that employ an online delivery system or LMS } \\
\text { in order to connect geographically separated students } \\
\text { and educators, both synchronously and asynchronously. } \\
\text { Students do not attend a class, and nearly all instruction } \\
\text { takes place online. }\end{array}$ \\
\hline
\end{tabular}

Source: Adapted from Evergreen Education Group (2015)

\section{Method}

This study uses the phenomenological approach. The qualitative method uses a combination of methods, such as online interviews (via email) documents and videos to understand the meaning participants place their own perspectives to provide insight into motivations on the 'telling' of a phenomenon. In this instance the experiences and voices of the staff Criminology and Forensic Studies, both permanent and fixed term contract, on resorting to online teaching and learning during the COVID-19 pandemic and lockdown of the University of KwaZulu-Natal. Online teaching and communication required a change in the method of pedagogy and module outcomes. Phenomenology is the study of structures of consciousness as experienced from the first-person point of view. It aims to describe, understand and interpret the meanings of experiences and focuses on research questions such as what it is like to experience a particular situation. In this study, the researcher generally understands the challenges faced by the Criminology and Forensic Studies Discipline during this pandemic to online teaching. It focuses on the lived experience of staff within an academic institution. Symeonidis and Schwarz (2016) attests that through this process the wide-ranging meaning of the phenomenon of achieving pedagogy, within a particular situation of experience can arrive at a more profound understanding of the preparedness of staff in dealing with online and digital technology.

Research was carried out with a small cohort of staff, 10 fixed term contract and six permanent (16 in total) within CFSD, therefore, it is not appropriate to attempt to generalize its findings to the entire academic institution. Staff worked across the Howard and Pietermaritzburg campuses. Ten of the fixed term staff responded to the survey and four of the permanent, providing a sample of fourteen participants. However, the findings of this 
study will be useful for management and senior members of staff in the School, to take cognisance of the experiences within CFSD in developing a pedagogically focused view of online teaching and learning. In order to understand the development of the discipline of Criminology and Forensic Studies at UKZN, it is of vital to contextualise the development of the subject, the cohort of students and the trajectory it has taken over the years.

\section{Criminology and Forensic Studies at the University of KwaZulu-Natal at Howard College and the Pietermaritzburg Campuses}

The University of KwaZulu-Natal (formally University of Durban-Westville), is an academic institution that offers teaching and learning with lecturers/ teachers coming into direct contact with their students, i.e. face-toface teaching. Furthermore, staff are encouraged to use different platforms to teach and communicate with students e.g. Moodle and Zoom. In order to understand the dynamics of teaching and learning within the Discipline of Criminology at the University of Kwa Zulu-Natal one has to understand the development of this tertiary institution holistically. The University of Durban-Westville was established in the 1960s as the University College for Indians on Salisbury Island in Durban Bay. In 1971, the College was granted University status. In 1972 the newly-named University of Durban-Westville (UDW) moved onto the campus in Westville and was a site of major antiapartheid struggle. University of Durban Westville became an autonomous institution in 1984, opening up to students of all races. The University of Natal was granted independent University status in 1949 due to its growth in student numbers, its wide range of courses and its achievements in and opportunities for research. The distinguishing Howard College building was opened in 1931.

The University of KwaZulu-Natal was formed on 1 January 2004 as a result of the merger between the University of Durban-Westville and the University of Natal. The two KwaZulu-Natal universities were among the first group of South African institutions to merge in 2004 in accordance with the government's higher educational restructuring plans that transformed the number of higher educational institutions in South Africa from 36 to 21. The mergers were a culmination of a wide-ranging consultative process on the 
restructuring of the Higher Education Sector that began in the early 1990s. The University of KwaZulu-Natal comprised of five campuses.

The Department of Criminology was located historically at the University of Durban Westville, and was established in 1976. Since then the Department has undergone many changes. Initially Criminology was 'housed' within the Faculty of Arts 1976 to 2000. In the Faculty of Arts Criminology was offered as a subject/module and a major to students studying within the Arts and as an elective to students from other Faculties. In the year 2000, due to restructuring of Faculties, the department of Criminology moved to the Faculty of Law.

In the merged institution of the University of KwaZulu-Natal, Criminology moved to the Faculty of Humanities because the discipline serviced students from various other departments e.g., Social Work, Psychology, Sociology and Law. In 2018 the name of the Programme of Criminology was formally changed to Criminology and Forensic Studies Discipline (CFSD) and was ratified by the Department of Higher Education (DHET). This is in keeping with the changes in the $21^{\text {st }}$ century Criminology and Forensic Studies in South Africa. In August 2018 the CFSD underwent its five year review process by the UKZN Quality and Assurance Committee. The review was very successful with positive feedback. Furthermore, a number of new staff have been employed and the student numbers have increased.

Table: 1 The approximate number of students in 2020 at the undergraduate and postgraduate levels (both Howard and Pietermaritzburg campuses)

\begin{tabular}{|l|l|}
\hline Undergraduate Level & Number of Students \\
\hline Level 1 & 1400 \\
\hline Level 2 & 530 \\
\hline Level 3 & 700 \\
\hline Postgraduate Level & \\
\hline Honours & 100 \\
\hline Masters & 60 \\
\hline PhD & 40 \\
\hline Total & $\mathbf{2 8 3 0}$ \\
\hline
\end{tabular}


In 2020, there were approximately 2650 students at the undergraduate level and 200 at the postgraduate level. There has also been an encouragement of collaborative work by instituting continuous workshops, projects with a view to identifying needs and form partnerships with NGO's and establish community-focused education to increase the African Scholarship. The table below indicates the approximate number of students registered for CFSD IN 2020.

The 'massification' of tertiary education had a result in the financial and human resources of the discipline. The result of the large numbers was the offering of different streams of the same module. At level 1 three streams are offered, one stream at level two and two streams at level three. More venues were allocated at the institution, more contract lecturers, tutors and mentors were employed to cater for the needs of the students. Contract staff were employed to supervise the mini-dissertation at the Honours level. Masters and $\mathrm{PhD}$ students were allocated to permanent staff, which led to an increased workload.

With the COVID-19 lockdown addressing the teaching and learning of a huge cohort of students via online platforms has proven challenging, not only for the students but for the staff as well as will be noted from their responses to the online questionnaire. The following responses are the perspective of academics within the CFSD on E-learning.

\section{Analysis of Data}

In analysis of the data, the researcher uses many direct quotes from the participants. Participants were asked how they were coping with teaching from home. It is important to note that many modules have multiple streams, for example at level one there are 3 streams, level 2 one stream and level 3 two streams in order to accommodate the students. Although the modules at different undergraduate levels offered in CFSD have many streams, the student teacher ratio is still extremely high. In level, one the ratio is approximately 1:400, level 2, 1:400 and level 3 is 1:300. At the Honours level, the ratio is $1: 100$, an extremely tenuous situation to conduct personalised teaching. Some of the participants in this study experienced challenges with E-learning. When asked, 'How lecturers were coping working from home (WFH)', the following responses are verbatim from the participants: 
It is difficult and challenging. Students do not have data and network especially those from deep rural areas. It is not easy but it is doable.

I am trying to cope but it is challenging, since I do not have all the necessary materials to work from home.

Teaching at home until now has been challenging since I do not have access to all facilities needed

Teaching at home is a bit difficult because I do not have all the facilities that I had when I was teaching at the University e.g. Moodle, zoom and emails

I am coping but a significant problem is students' poor response to the zoom online teaching.

Other participants were more positive and optimistic about the online teaching and access to information by the students:

At the last schoolboard meeting, we were told that online teaching would begin on 4 May 2020. However, I do keep contact with students via Moodle and email. I uploaded all the lecture slides and readings as advised at the previous meeting. Students also contact me via email when they have questions regarding the content and the assignment. I have also informed the students that the lecture recordings will be uploaded in due time. I am also communicating with the level administrator, I have sent her the test papers, which will be uploaded on Moodle, but students will only be able to access the papers when we resume campus.

Another participant stated:

I am currently coping well. I am uploading as much material as possible for students to access on Moodle. I have also revised the assignment question, made it simpler, and narrowed it down. I have sent an email to all my students asking them how they are coping and if they have any challenges they are facing currently, so that I can plan accordingly to accommodate everyone. 
Participants were asked if they experienced any challenges (if any). Many of the participants experienced challenges with technology, course content and interacting with students. According to Wallace (2009) understanding the realities of online learning includes coming to terms with the limits of educational technology, both pedagogical and technical. Even with well-constructed technology, breakdowns are not uncommon, and software usability issues can severely hinder the effectiveness of otherwise sound curricula. Some of the responses highlight tensions, anxiety and challenges:

Students have not been positioned to engage learning in this fashion. I think lack of resources is the main issue for the students. This form of learning will require lecturers to be patient and leave room for those who will be struggling to meet us halfway. In addition, my laptop had given up on me early this year but it was sorted this week so I am very happy about that. I will not speak to the issue of staff data as the School has made those arrangements already.

Responding to each student's email can be draining more especially if it is something than can be well clarified in class. Students are struggling with data to access internet and other valuable resources (which would be normally available on campus) to finalise their research assignment.

The challenge for now is that I do have students who do not have internet connection, smart devices and computers to follow up what the lecturer uploaded, to conduct online sections and to submit the assessment via Moodle online. Online teaching without material is problematic.

Inability to engage with all students is a bit challenging. I do not know the issues each student is facing, if they have laptops and internet, and are able to work from home. I hope that a majority of the students will respond to my email and state their challenges. I also have a challenge with planning for assessments. I am not familiar with methods of online assessments and how to set up different forms of assessments for students. 
Just worried about the sudden change in the teaching system. We are dealing with first years of whom the majority of them are lacking computer skills. It becomes problematic for them to master the online teaching in the sense that they do not have proper guidance but also a huge number of our students are from rural areas where they are struggling with an internet connection and still some have no easy access to computers. I suggest that the University thinks of possible ways to deal with this as soon as possible so that we can have all our students on track.

I have many challenges because I am dealing with 1st-year students. Firstly, most of them are not computer literate; therefore, they have some problems with online teaching. Computer literacy issues are mainly amongst first-year students. Secondly, based on the VC email that has been circulated yesterday (6th of April 2020), a cohort of 2020 first-year students have still not been issued with NSFAS laptops as a result of COVID-19. Challenges in China where the shipment of the laptops was delayed as a result of the port closures. Therefore, most disadvantaged students (NSFAS students who constitute $70 \%$ of my students) will not have laptops (the tool that will facilitate them with online teaching).

We have challenges with students being at home and not being able to complete their assignment but we have extended the assignment submission date to accommodate them. The class reps have sent me emails that students are unable to access the materials because of network and internet issues from their homes. The issue of lack of data was also raised, which resulted in poor correspondence from the students with engaging the material sent to them.

Participants also indicated that some were still in the process of learning digital teaching. The challenges faced by staff and students is in keeping with a study done by Anderson and Gronlund (2009) titled 'a conceptual framework for E-Learning in developing countries: a critical review of research challenges', which identified challenges associated with e-learning namely course challenges, challenges pertinent to individual characteristic of students and teachers, technical challenges and contextual challenges. 
The United Nations Educational, Scientific and Cultural Organization (UNESCO) states that migrating from traditional learning to virtual learning and online delivery strategy, will not happen overnight. This is associated with many challenges such as lack of home office infrastructure for academic staff, lack of online access infrastructure for students from remote areas, internet restrictions by government and lack of general skillsets needed to professionally design and offer virtual education (UNESCO 2020). This is in keeping with the challenges experienced by majority of the CFSD participants in this study.

The modes of technology used by the participants varied.

Moodle, Emails, WhatsApp, Zoom -WhatsApp is especially effective for Supervision of Honours Students. The platform is exceptionally productive and conducive. I am literate with loom and zoom as methods of teaching. I am still struggling with tools used for assessments such as Moodle quizzes. However, I am hoping to attend more training to address that.

Furthermore, some participants used different forums on Moodle for different aspects of their work. For lectures,

... power point with audio recordings and/or lecture recordings uploaded in Moodle; consultations and tutorials are conducted via 'Moodle Forum Discussion'.

Some participants were still in the process of acquiring the skills on the use of digital and online platforms, which was new to them. One participant attested:

I have only used Moodle, but I have joined digital teaching online training workshop. I have also attended a Zoom training that was facilitated by a colleague from Edgewood campus last week.

Participants were asked as to their vision for a way forward regarding teaching and learning online within CFSD. Many of the responses were similar, indicating that the institution should be organised to empower both staff and students with the technological aspects of online teaching. Some 
suggestions indicated that as a discipline workshops within the SAHS would benefit staff to effectively use Moodle as a tool to teach and mark the assessments on the system. Besides teaching and learning, the COVID-19 virus has caused much anxiety, uncertainty and stress on both staff and students.

With proper planning and resources, all of us can align with the UKZN proposed teaching method. I am optimistic that we can serve students even under these dire circumstances. If both staff and students are provided with, all the necessary resources needed for online teaching and learning then progress would be made.

We need weekly meetings as a discipline. Working alone and from home provokes anxiety. Weekly meetings can assist staff to learn from each other and share ideas, and to just know where we all stand together as a discipline during this period.

Another participant was a bit despondent and said,

In this case, I feel like things or circumstances must be fair for all our students. Yes, we upload the module materials and assessments, and then proceed with online lecture. Students who do have access will be following us and can cope with the online learning, the concern is how about students who do not have internet access? The university have to work to provide devices for students, make sure that all have internet connection and ensure they can access the materials we uploaded. Otherwise, it will be very difficult for us lecturers to evaluate their assignment, test and exam. Therefore, I personally recommend, the university to provide computers and internet access for students urgently.

The way forward, first the University should ensure that all our students (mostly undergraduates) have access to computers and an internet connection and they can easily do their academic work with not much stress. Lecturers should make video presentations-each video should be less than 30 minutes, explaining the content of the notes to provide a clear understanding of the module to our students. If possible, disseminate of information on any possible training of staff within the School 
and the University at large, in connection with the remote system so that we can all be on the same page for the betterment of the teaching system.

As the way forward for me, to facilitate my teaching, I would ask the university to do its best to allocate laptops and data to students as soon as possible. This will facilitate online teaching. Furthermore, a suggestion is also to extend the deadline of assignments' submission up until the end of May. This will permit all students, especially NSFAS students who do not have laptops up until now, to be able to complete and submit their work online.

As some of these students do not have internet source at their villages while some complained of computer, my suggestion is for every lecturer to deliver their video lectures and upload on the student-learning platform (Moodle). They can access it at their convenience and respond to the concerned lecturer if need be.

Online teaching for me as a lecturer is still a bit frightening due to being unfamiliar with setting up various technological platforms. However, I am very excited to learn how to use them and effectively deliver lectures to all of our students. With our large student numbers, my main concern lies with the students that do not have laptops, internet access or even conducive home environments that allow successful teaching and learning to occur. Way forward is reaching inclusiveness of online teaching and learning so that it can be equally accessible and beneficial to the majority of our disadvantaged students. I think we also need to take cognisance of our disabled students when using the online platforms for teaching and learning.

The responses of the participants indicate that higher education institutions need to provide specialised development and training for lecturers. Furthermore, more intense technical support for the use of online platforms and delivery of online courses to address the challenges in online education and improve the effectiveness of online teaching and learning should be provided. Although at UKZN, the University Teaching and Learning Office provides various workshops/webinars on the use of Moodle, Zoom and Kaltura (start in May 2020), it seems that it will take some time 
for some staff to become proficient in these portals. Higher education institutions play a fundamental role in improving the quality of online education. The lockdown has several implications for universities in South Africa. Universities have sent their students home and they have been informed that the second term will be completed online. There are four critical issues that universities have to consider to make their online undertaking a success; affordability, connectivity, assessment and student support. The most important of these four issues are affordability and connectivity (Cloete 2020).

\section{Conclusion and Recommendations}

Given the global pandemic of COVID-19, which has brought the entire world into shutdown and seemingly turned the world 'upside down', and academic institutions into a virtual closure and uncertainty, the task of management is to ensure that the integrity of UKZN is maintained within the scenario that is playing out. This global crisis and the weeks of lockdown implemented by most countries around the word has led to people working from home. In a virtual environment, meetings are held using different platforms, teaching and learning done using various virtual tools or environments. In the wake of the emergence of new modes of digital communication, higher education has entered a time to undertake robust transformation that has to create new possibilities for collaborative, engaging scholarship and teaching with a goal to advance the vision of the academic institution as an excellent institution in the 21 st century. This would entail combining traditional teaching and research with new forms of digital scholarship intended to involve a wider audience. The SAHS will need to be innovative and collaborative if it is to raise its profile yet further and take a leadership role in shaping the future of higher education. This means taking into account the purpose of the modules taught, the needs of the students, the social transformation taking place in South Africa, the diverse student population and the changing needs of higher education. A new form of a university is emerging that does teaching, research and service in a different manner. E learning is not only growing into an accepted mode of teaching, but will require continuous adaptation to meet the needs of a changing world.

To this end future research might include examining the perceptions of these students in a variety of online environments, conducting action 
research using various virtual learning tools or models, or observing more closely how the online teaching evolves. It would be highly recommended that further research be conducted on teachers' roles in online classes intended specifically for students from diverse social backgrounds. While face-to-face courses can often rely on in-depth debates and discussions for a continued period during a class session, online courses sometimes have a more difficult time engaging learners in 'deep' conversations. As technology and learning platforms continue to change in the coming years, there is no doubt that how students learn online will evolve? Continuous developments in how information is communicated and strategies for increasing learner engagement with content require that online course designers stay current with new tools for online course development. By following best practice standards of online course creation and appropriately aligning learning activities with learning outcomes, course designers can ensure that they are providing the highest quality learning opportunities and are fully leveraging the potential of online learning (Kenzig 2015:4). Leading colleague's towards a goal requires not only orientation and motivation but it is equally imperative to empower staff to effectively implement strategies to achieve the shared goals. This requires operative management practices to create an enabling environment to take the discipline of CFSD within SAHS to the next level. This is in keeping with ensuring that the mission statement of UKZN remains 'A truly South African University and a school of choice that is academically excellent, innovative in research, entrepreneurial and critically engaged with society'. Research and scholarship into online education is enormous and always increasing. Persistent progress of new technologies and novel ways to convey and conduct online learning gives rise to new areas of research and creates the need for further development of prevailing scholarship.

\section{References}

Allen, I. E. \& J. Seaman 2014. Grade Change: Tracking Online Education in the United States. Newburyport, MA: Sloan Consortium.

Anderson, D., S. Imdieke \& N.S. Standerford 2011. Feedback Please: Studying Self in the Online Classroom. International Journal of Instruction 4: $3-15$.

https://doi.org/10.1002/j.1681-4835.2009.tb00271.x 
Anderson, A. \& A. Gronlund 2009. A Conceptual Framework for E-Learning in Developing Countries: A Critical Review of Research Challenges. Electronic Journal of Information Systems in Developing Countries 38,8,July: 1 - 16. Available at:

https://www.researchgate.net/publication/228641067 A Conceptual Framework_for_E-

Learning_in_Developing_Countries_A_Critical_Review_of_Research (Accessed on 15 April 2020.)

Avgerinou, M.D. \& C. Andersson 2007. E-moderating Personas. Quarterly Review of Distance Education 8: 353 - 364.

Behari-Leak, K \& R. Ganas 2020. Going Online - What Cost to the Social Justice Agenda? 2 April 2020. University World News. Available at: https://www.universityworldnews.com (Accessed on 15 April 2020.) https://doi.org/10.18356/15645304-2020-1-19

Britain, S. \& O. Liber 1999. A Framework for Pedagogical Evaluation of Virtual Learning. Available at:

http://www.jisc.ac.uk/uploaded documents/jtap-041.doc (Accessed on 14 April 2020.)

Cloete, J. 2020. SA Universities are Failing to Meet the Challenges of Teaching during the COVID-19 Lockdown. 9 April 2020 Daily Maverick Available at: https://www.dailymaverick.co.za/

(Accessed on 15 April 2020.)

Evergreen Education Group 2015. Keeping Pace with K-12 Digital Learning: An Annual Review of Policy and Practice. Available at: https://www.inacol.org/wp-content/uploads/2015/11/KeepingPace2015-Report-1.pdf (Accessed on 15 April 2020.)

Garrison, D. R. 2017. E-learning in the $21^{\text {st }}$ Century: A Community of Inquiry Framework for Research and Practice. $3^{\text {rd }}$ Ediiton. Routledge

Hill, J.R. 2002. Overcoming Obstacles and Creating Connections: Community Building in Web-based Learning Environments. Journal of Computing in Higher Education 14: 67 - 86.

https://doi.org/10.1007/BF02940951

Kahn, T. 2020. Early Recess Ordered at all Higher Education Institutions due to COVID-19. 17 March 2020 - 18:23. Available at: https://www.timeslive.co.za/ (Accessed on: 16 April 2020.)

Kenzig, M.J. 2015. Lost in Translation: Adapting a Face-to-Face Course into an Online Learning Experience. Health Promotion Practice 16,5: $625-$ 
628. https://doi.org/10.1177/1524839915588295

PMid:26202772

Limperos, A. et al. 2015. Online Teaching and Technological Affordances:

An Experimental Investigation into the Impact of Modality and Clarity on Perceived and Actual Learning. Computers \& Education 83: 1 - 9.

https://doi.org/10.1016/j.compedu.2014.12.015

Luyt, I. 2013. Bridging Spaces: Cross-cultural Perspectives on Promoting

Positive Online Learning Experiences. Journal of Educational

Technology Systems 42: 3 - 20.

https://doi.org/10.2190/ET.42.1.b

Peng, H., C.C. Tsai, \& Y.T Wu 2006. University Students' Self-efficacy and their Attitudes toward the Internet: The Role of Students' Perceptions of the Internet. Educational Studies 32: 73 - 86.

https://doi.org/10.1080/03055690500416025

Roper, A.R. 2007. How Students Develop Online Learning Skills. Educause Quarterly 30: 62 - 64.

Social Science Space 2020. 16 Answers to Your Questions about Teaching Online. 16 March 2020. SAGE. Available at:

www.socialsciencespace.com (Accessed on 17 April 2020.)

Symeonidis, V. \& J.F. Schwarz 2016. Phenomenon-Based Teaching and Learning through the Pedagogical Lenses of Phenomenology: The Recent Curriculum Reform in Finland. European Union's Horizon 2020. Available at:

http://www.edite.eu/wp-content/uploads/2017/11/Phenomenon-basedteaching-and-learning-through-the-pedagogical-lenses-ofphenomenology (Accessed on 18 April 2020.)

Tsai, C.C. \& C.C. Lin 2004. Taiwanese Adolescents' Perceptions and Attitudes Regarding the Internet: Exploring Gender Differences. Adolescence 39: 725 - 734.

UNESCO, 2020. Combat COVID-19: Keep Learning. Together we are on the Move! Available at: https://iite.unesco.org/combating-covid-19together-we-are-on-the-move/

(Accessed on 15 April 2020.)

Vai, M. \& K. Sosulski 2016. Essentials of Online Course Design: A Standards-based Guide. New York, NY: Routledge. https://doi.org/10.4324/9781315770901 
Wallace, P. 2009. Distance Learning for Gifted Students: Outcomes for Elementary, Middle, and High School Aged Students. Journal for the Education of the Gifted 32: 295 - 320. https://doi.org/10.4219/jeg-2009-855

Professor Shanta Balgobind Singh Criminology and Forensic Studies School of Applied Human Sciences, Howard College Campus University of KwaZulu-Natal Durban singhsb@ukzn.ac.za

Dr. Gerelene Jagganath Anthropology School of Social Sciences Howard College Campus University of KwaZulu-Natal Durban pattundeeng@ukzn.ac.za 